\title{
SOME OBSERVATIONS REGARDING RE-ELECTIONS IN PROVINCIAL COURT UNDER THE CRIMINAL CODE IN ALBERTA \\ PERCY MARSHALL*
}

\begin{abstract}
Judicial interpretation of the Criminal Code provisions, sections 464 and 484, relating to re-election for trial, has become increasingly restrictive. Through a thorough historical analysis of the relevant case law, the author demonstrates that the right to apply to re-elect has, in certain circumstances, been virtually removed in Alberta. Criticisms of the present trend are offered, followed by proposals for reform.
\end{abstract}

This paper concerns itself with two situations that may arise after an accused has made his election, in accordance with sections 464 and 484 of the Criminal Code, as follows:

(a) Where an accused, who has elected to be tried by a judge alone, or a judge and jury, and who prior to his committal, for tactical or other reasons, wishes to convert the proceedings "downwards" to a trial before the Provincial Court;

and,

(b) The opposite situations, where an accused having elected trial before a Provincial Judge, and prior to "entering upon his defence", for the same sort of reasons, wishes to convert the proceedings "upwards" to a preliminary hearing (i.e. trial by a judge alone or judge and jury).

\section{STATUTORY AUTHORITY}

The only statutory provision in the Criminal Code regarding the rights of an accused to re-elect after he has made his election pursuant to sections 464 and 484 are set out in sections 491 and $492 .^{1}$

\footnotetext{
Section 491(1)-Where an accused has elected under section 464 or 484 to be tried by a judge without a jury he may, at any time before his trial, with the consent in writing of the Attorney General or counsel acting on his behalf, notify a magistrate having jurisdiction that he wishes to re-elect under this section. [Emphasis added.]

Section 492(1)-Where an accused has elected or is deemed to have elected to be tried by a court composed of a judge and jury, the accused may notify the sheriff in the territorial division in which he is to be tried that he desires to re-elect under this section,

(a) to be tried by a judge without a jury; or

(b) if he has the consent in writing of the Attorney General or counsel acting on his behalf, to be tried by a magistrate without a jury. [Emphasis added.]
}

Section 497, dealing with the "discretion" of a magistrate where there is more than one accused and they do not all elect the same, and section 499 , regarding continuance of proceedings where the magistrate is unable to act, are considered to be too remote for this article and have not been considered. Section 498, dealing with the right of the Attorney General to require a trial by jury where the offence is punishable for more than five years, notwithstanding the election or re-election of the accused, is referred to later in this paper.

* Judge, of the Provincial Court of Alberta.

1. In Alberta, by the definition in $\$$. 482(a), a magistrate means a "Provincial Judge". 
Therefore the only other statutory provision in the Code which is relevant to the re-election situation that this article is concerned with is section $485(1)$.

Section $485(1)$ - Where in any proceedings under this Part an accused is before a magistrate and it appears to the magistrate that for any reason the charge should be prosecuted by indictment, he may, at any time before the accused has entered upon his defence, decide not to adjudicate and shall thereupon inform the accused of his decision and continue the proceedings as a preliminary inquiry. [Emphasis added.]

Regarding Section 485(1), immediately aforesaid, it will be observed that "this Part" is Part XVI of the Criminal Code entitled "Indictable Offences-Trial Without Jury". It will be observed further that the discretion given to the Provincial Judge is very broad and general ("for any reason" and "at any time before the accused has entered upon his defence"). Furthermore, this discretion appears to lie with the Provincial Judge for all electable indictable offences and for all Crown option offences even where the Crown elects to proceed summarily. It would not apply, however, to offences of absolute jurisdiction of a Superior Court as set out in Section 427; nor would it lie with offences over which the Provincial Judge has absolute jurisdiction (Section 483) except in the case where at trial, before adjudication, the evidence establishes that the value of the subject matter of the charge concerned exceeded $\$ 200.00$. In such a case Section $485(2)$ applies and the accused must then be given his election (as per 484(2)) and depending upon that election, the proceeding continues as a trial or becomes a preliminary.

This contrasts with the situation where the Provincial Judge exercises his discretion under $485(1)$ and converts the trial to a preliminary inquiry. All that is required is for the Provincial Judge to advise the accused that the proceeding is now a preliminary, and the accused is not given any election nor, it seems clear, any choice but to accept that the proceeding has become, thereafter, and without more, a preliminary. It follows from this that the Crown evidence given to that point at trial would become its evidence on the preliminary. As was observed by Lamer J. for the Supreme Court of Canada in Matheson v. The Queen ${ }^{2}$ :

My reading of s. $451(l)$ is that, in such a case the Magistrate need not read the trial evidence into the inquiry's record. Parliament differentiated between the two situations no doubt because evidence admissible at an accused's trial will of necessity be so at his preliminary, but not necessarily conversely.

If there should be a committal for trial at the conclusion of the preliminary, it would proceed to trial as after any committal for trial after any preliminary, except that, by virtue of $\mathrm{s}$. 495(b), he shall be deemed to have elected trial by judge and jury, where the Magistrate invokes s. $485(1)$.

Section $485(1)$ seems to be a rather extraordinary section of the Code, the significance of which will be developed further in this paper. It seems clear that it overrides the election of an accused for trial by Provincial Judge, notwithstanding that the election is given ostensibly for the benefit of the accused to let him choose his method of trial. ${ }^{3}$

2. (1981) 59 C.C.C. (2d) 289 at 291 (S.C.C.).

3. The Attorney General can also override the election by the accused and require a trial by jury in certain cases as per s. 498. 
Indeed, in the 1973 Ontario Court of Appeal decision of $\operatorname{Re}$ Neilson and The Queen it was decided that "section 484 is overridden by and subject to section $485(1) " .4$ As a result, the accused could not allege that the Provincial Judge lost jurisdiction when he would not accept the election for a Provincial Court trial and call upon the accused to plead, but proceeded with a preliminary under his "right" in section 485(1). It should be mentioned that Fauteux J. for the majority of the Supreme Court of Canada stated, in dismissing the appeal by the accused and agreeing with the Ontario Court of Appeal, that "while the procedure adopted at the preliminary inquiry may have been somewhat unusual there is no prejudice to the accused."'5 It will be noted that the Ontario Court of Appeal refers to the discretion given to the Provincial Judge in section 485(1) as being a "right to decide that he will not try the accused but will proceed on the preliminary inquiry"'.6

In summary then, the statutory right of re-election of the accused is quite restrictive. It is worded as being conditional upon the Crown's consent, and is subject to the possible implementation of sections 497 and 498 in certain circumstances. It is, in all likelihood, confined to only those cases where the preliminary hearing has been completed or waived, and the accused has been committed for trial (because of the words "at any time before his trial" in section 491 and the words "in which he is to be tried" in section 492). However, on this latter point, Alberta Provincial Court Judge J.P. Wambolt, in his thoughtful, well reasoned, written submission entitled "The Preliminary Inquiry-Re-election of Magistrate Without Jury",7 suggests that the words "at any time before his trial" in section 491 (re-electing from a judge alone downwards to Provincial Court) means both before and after committal, which, he submits, makes it different from the cases under section 492 (judge and jury downwards to Provincial Court). He states further that his research revealed only one case which deals with any distinction between sections 491 and 492: the 1976 Alberta Court of Appeal decision in $R$. v. Broder, Flaa and Johnston where McDermid J.A. speaking of sections 491 and 492 states, "However I think the interpretation of both sections is the same in regard to the right of the accused to re-elect." 8

This distinction proposed by Provincial Judge Wambolt is a neat one, but seemingly contrary to the aforesaid opinion of McDermid J.A., and to $R$. v. MacRitchie, where Farris C.J. states, "[i]n my view analysis of section 491 compels the conclusion that that section refers to the situation of re-election after committal for trial." Also, it could be argued that the use of the word "trial" in section 491 would be redundant and would have no application unless and until there had been a committal for trial
4. (1973) 11 C.C.C. (2d) 532 at 533 (Ont. C.A.).
5. (1973) 14 C.C.C. 321 (S.C.C.) at 321.
6. Supran. 4 at 533.
7. “The Preliminary Inquiry - Re-election of Magistrate Without Jury," Judge J.P. Wam- bolt, prepared for a Judge's seminar (1981).
8. (1977) 32 C.C.C. (2d) 55 at 59.
9. [1976] 3 W.W.R. 661 at 663 (B.C.C.A.). 
by the completion or waiver of a preliminary hearing. ${ }^{10}$ It is clear that there is no statutory right of re-election upwards where the accused has elected trial by Magistrate, and there does not appear to be any statutory right for the accused to re-elect downwards to Provincial Court before his committal for trial. It follows, then, that if there is any other authority, it must be found in the relevant cases.

\section{CASE LAW AUTHORITY}

It seems reasonable to divide the time period concerned into three sections, namely (a) the "pre-Davies (Doyle)" period, (b) "Davies (Doyle)", and (c) the "post-Davies (Doyle)" period. This is so because, as was clearly pointed out by Shelley L. Miller, in a detailed, wellresearched case comment entitled " $\mathrm{Re}$-election for Trial at Preliminary Inquiry: $R$. v. Davies" "1 the decision of the Alberta Court of Appeal in $R$. v. Davies, ${ }^{12}$ which interprets and applies the Supreme Court of Canada decision of Doylev. The Queen ${ }^{13}$ to a re-election situation, may well have "excluded the right of re-election altogether" - at least in Alberta. ${ }^{14}$

\section{A. PRE-DA VIES (DOYLE) CASE LAW AUTHORITY}

It seems fair to suggest that this period is marked by the evolution of a movement beginning with severe restrictions on the right of the accused to re-elect and culminating with his quite liberal rights to do so. A brief summary of the restrictive cases follows:

In $R$. v. Scown, ${ }^{15}$ Harvey C.J.A. for the Alberta Court of Appeal held that, where the Magistrate converted a preliminary hearing to a trial at the end of the Crown's case in accordance with "common practise" and with the consent of the Crown, the Magistrate still had no jurisdiction to convert to a trial, because consent cannot give jurisdiction. Therefore, his subsequent conviction was without jurisdiction. The case was remitted back to the Magistrate to "complete the preliminary enquiry".

In $R$. v. Siniaski, ${ }^{16}$ the accused, with Crown consent, re-elected from judge and jury downwards to Magistrate's Court before any evidence was heard, pleaded guilty, and was sentenced. The conviction was set aside because the Magistrate had no jurisdiction to follow this procedure.

10. However, there may be support for Judge Wambolt's position in the statement of Lamer J. in the Supreme Court of Canada decision of Matheson (supra n. 2 at 290) which is dealt with in more detail later in this paper. Such a distinction, but for another purpose, may be recognized in the Crown's preferring an indictment to include, additionally, counts relating to offences disclosed by the evidence at the preliminary hearing, where the election is judge alone, and section 496(2)(b) can apply. No similar section or power is found in section 507 which would govern, by elimination, the preferring of an indictment, where the election is judge and jury.

11. (1982) XX:2 Alta. L. Rev. 340.

12. $[1979] 6$ W.W.R. 1.

13. (1976) 29 C.C.C. (2d) 177.

14. Miller was, of course, clearly, not including any statutory rights thereto, as in sections 49] or 492 .

15. (1945) 84 C.C.C. 277 at 282-3.

16. (1966) 63 W.W.R. 52 at 53. 
The information was returned to him "for disposition in accordance with the provisions of the Criminal Code". Culliton C.J., for the Saskatchewan Court of Appeal, suggested that if the first election is "invalid", there would be no election and the accused could then make a "proper election". This case, dealing with a re-election application before the preliminary hearing commenced, would seem to be the most extreme position against any re-elections, and it was given prior to the enactment of sections 491 and 492, which gave the statutory power to reelect.

R. v. Hunter and McInroy 17 is a Saskatchewan Court of Appeal decision which, although subsequent to the Doyle case, makes no mention of it, and is therefore included here. At the end of the preliminary, after the warning was read (section 469), each accused re-elected downwards to Provincial Court with the consent of the Crown. Hunter pleaded guilty but his appeal, based upon "no jurisdiction in the Magistrate" was not allowed, although the sentence was reduced. McInroy pleaded not guilty and was convicted. On his appeal, a new trial was ordered because there was no application made to have the evidence at the preliminary become the evidence at trial. Therefore, there was no evidence upon which he could be convicted. Hall J.A. stated that "Without necessarily adopting in full the reasoning in $R$. v. Scown, the conviction of McInroy must in any event be quashed and a new trial ordered." 18

Miller and The Queen ${ }^{19}$ is a decision of Bence C.J.Q.B. of Saskatchewan Queen's Bench which deals with proposition (b) spelled out at the outset of this paper; namely, conversion from Provincial Court upwards to a preliminary hearing. It is included here because, although it upholds the Magistrate's decision not to allow a re-election, ${ }^{20}$ it may also extend somewhat the proposition enunciated in $R$. v. Siniaski, ${ }^{21}$ i.e. to consider an election made due to a "mistake" or "mis-understanding" as amounting to no election with the entitlement of the accused, thereafter, to then make a proper election. In this case the Magistrate did not agree to the reelection upwards, but Bence C.J.Q.B. suggests that his "off-hand view" was that if the Magistrate, the accused, and the Crown all agreed, then the accused would have submitted to the jurisdiction of the judge alone or judge and jury as the case may be and, assuming a committal, he could not later attack that jurisdiction.

It is suggested then that these latter two cases, Hunter and McInroy and Miller, although often included in the same camp as Scown and Siniaski, may indicate some movement away from acceptance of the strict principle enunciated therein, at least in obiter.

17. [1978] 6 W.W.R. 88 .

18. Id. at 91 .

19. (1973) 11 C.C.C. (2d) 338.

20. On that point it spells out and calls attention to s. $485(1)$, the Magistrate's discretion to convert to a preliminary.

21. Supran. 16. 
The major changes began with the 1966 Ontario Court of Appeal decision in $R$. v. Fairbairn. ${ }^{22}$ In this case the accused elected trial by judge and jury. Before the preliminary commenced, with Crown consent, defence counsel applied to re-elect downwards to Provincial Court. The accused pleaded not guilty and was later tried and convicted in Provincial Court. He appealed on the grounds that the Magistrate had no jurisdiction to permit such re-election. ${ }^{23}$ The Court held that since section 468 (now 484) does not preclude this type of application, and since the accused was represented by Counsel, had Crown consent, and made the application before the preliminary "had been launched", it would be a travesty of justice to later permit the accused, after conviction, to impeach the Magistrate's jurisdiction.

The Ontario Court of Appeal moved further along the road in the majority judgment in $R$. v. Cooper. ${ }^{24}$ They accepted the statement of principle in Fairbairn that because the Code has not forbidden such a procedure, the Magistrate had jurisdiction and could entertain an application to re-elect. They further extended it by stating: "on principle, [the Magistrate should] be entitled to exercise that discretion at any time until committal for trial when he would, as we have said, then have lost jurisdiction." 25 It will be recalled that this decision was before sections 491 and 492 were enacted.

In Cooper it may have been significant, as a practical consideration, that the stated purpose of the re-election was for the accused to plead guilty after his re-election. However, McDermid J.A. in $R$. v. Broder disagrees, and states: "Although the Court said that the purpose of the re-election was to plead guilty I do not think this played any part in the decision." ${ }^{26}$ He refers to the dissenting judgment of Laskin J.A., as he then was, who held, in his strong dissenting judgment, that the Fairbairn position (permitting re-election before the preliminary started) was a reasonable, practical compromise but that once the preliminary had begun the Magistrate was committed and must complete it. The only way, thereafter, that the accused could re-elect, would be for the Magistrate to discharge the accused, followed by a new information and election. Consent of the Crown could not bestow jurisdiction, nor was the fact of an intended guilty plea relevant, because consideration of the plea arises only after the matter of jurisdiction to permit re-election has been resolved (after the fact). ${ }^{27}$

The Cooper case was upheld by the Supreme Court of Canada, where, without calling upon counsel, it confirmed the majority decision of the Ontario Court of Appeal. We are now at the point where with consent, and with a guilty plea, the Magistrate may permit re-election downwards

22. [1967] I C.C.C. 76 .

23. This argument was upheld in Scown on different facts, and in Siniaski on similar facts but with the added factor of a guilty plea.

24. [1968] 2 C.C.C. 104.

25. Id. at 109 .

26. Supran. 8 at 58.

27. Supran. 24 at 110. 
to Provincial Court at any time prior to committal. As a result of Cooper, the Criminal Code was amended by adding sections 491 and 492.

The British Columbia Supreme Court decision in $R$. v. Cross ${ }^{28}$ extended the re-election to a not-guilty situation. Cross was adopted by the British Columbia Court of Appeal in the case of $R$. v. MacRitchie, which held that section 491 did not prevent an accused from re-electing downwards to Provincial Court for trial prior to his committal, and confirmed further that this right of the accused to apply to re-elect existed even without Crown consent and even where the accused proposed to plead not guilty. That is, MacRitchie extended Cooper and held that sections 491 and 492 had application only after committal.

To bring the situation directly to Alberta, the Alberta Court of Appeal in $R$. v. Broder ${ }^{29}$ held that the Cooper decision overruled Scown. The Court of Appeal agreed with the reasoning in MacRitchie that the right to apply to re-elect was open to the accused up to the time of committal, did not require the Crown's consent and could be done with a not-guilty plea. In a sense, Broder also extended MacRitchie to permit re-election downwards from a judge and jury election as well as from a judge alone election. It could also be done, of course, after committal as per sections 491 and 492 , but Crown consent would then be necessary.

In summary, then, prior to Davies, the position in Alberta seemed to be settled by Broder that an accused had the right to apply to re-elect downwards to Provincial Court for trial without Crown consent. ${ }^{30}$ In Broder the Crown asked the Provincial Judge to disqualify himself but was unsuccessful and the same Provincial Judge dismissed the charge. The Court of Appeal upheld the dismissal. In $R$. v. Nolin, ${ }^{31}$ Provincial Judge Carr, in a factual situation similar to Broder, held that he need not disqualify himself since such would defeat the whole purpose of a"fast" trial. Alternatively, an adjournment could be granted for further Crown evidence to complete the trial, if need be (presumably a fairly short adjournment, or else it would not be a "fast" trial). Nolin was appealed and the majority of the Manitoba Court of Appeal ${ }^{32}$ held that the Provincial Judge, having made rulings regarding the admissibility of statements which were adverse to the Crown at the preliminary, would be in a position at trial where "there was a reasonable apprehension of bias in that the Provincial Judge might be perceived as not being able to approach the determination of the important issue of the admissibility of the accused's statement with an open mind". 33

28. (1971) 1 C.C.C. (2d) 337.

29. Supra n. 8.

30. Quare what would happen if the Crown refused to agree to have the evidence apply from the preliminary to this trial? Would the Provincial Judge then order the Crown to start over from the beginning of the trial with a risk of dismissal if they did not, and could the Crown then argue prejudice or bias? Matheson states that where a Magistrate invokes section 485 (1) the "trial" evidence automatically becomes the "preliminary" evidence for the accused and his consent is not necessary. It may follow that this would be so for any conversion from "trial" to "preliminary" for the accused.

31. [1981] 6 W.W.R. 359 (Man. Prov. Ct.).

32. [1982] 6 W.W.R. 1 (Man. C.A.).

33. Id. at 1 (headnote). But see also the strong dissenting judgment of Huband $\mathbf{J}$.A. 
The Nolin appeal decision also refers to the "classic" $R$. v. Atkinson ${ }^{34}$ case in Manitoba in 1976 where, on a charge of drug trafficking, the accused successfully re-elected downwards to a Provincial Judge during the preliminary, so that the Certificate of Analysis, which would have been admissible at the preliminary without notice, was ruled inadmissible at trial because of lack of notice. The charge was therefore dismissed. The Manitoba Court of Appeal ${ }^{35}$ held that the result of this "changing the rules in the middle of the game" was "manifestly unfair to the Crown" and the Crown appeal was allowed. Atkinson subsequently went to the Supreme Court of Canada, ${ }^{36}$ where both the Manitoba Court of Appeal decision and the Magistrate's acquittal were set aside because no plea was taken from the accused after the re-election downwards and, therefore, there was no legal trial.

In Alberta, then, we were now at a point where Scown was considered overruled by Cooper, and an accused could re-elect downwards to a Provincial Court Trial and plead not guilty without the Crown's consent, whether the election had been judge alone, or judge and jury.

\section{B. DAVIES (DOYLE) CASE AUTHORITY}

The decision of Ritchie J. of the Supreme Court of Canada in Doyle v. The Queen ${ }^{37}$ was pronounced in 1976. Like the Cooper decision, it led to changes in the Criminal Code, specifically, the addition of section 440.1 regarding the "no loss of jurisdiction" provisions relating to adjournments or remands.

That was not the end of Doyle, however, and although it remained fairly quiescent for some time, it hit the Alberta scene full force in $R$. v. Davies. ${ }^{38}$ In its starkest terms Doyle held that an adjournment, either before or following the reading of the charge to an accused, for more than eight days and without the consent of the accused, and/or the failure of the Magistrate to put the accused to his election "as required by the Code" (sections 464 and 484), resulted in a loss of jurisdiction over the person of the accused. That proposition was clearly unquestionable in view of the relevant sections of the Code, and in the absence of section 440.1 .

The many ramifications flowing from the Doyle decision arise from the statement made by Ritchie J.: ${ }^{39}$

Whatever inherent powers may be possessed by a Superior Court Judge in controlling the process of his own Court it is my opinion that the powers and functions of a magistrate acting under the Criminal Code are circumscribed by the provision of that statute and must be found to have been thereby conferred either expressly or by necessary implication.

\footnotetext{
34. (1976) 32 C.C.C. (2d) 361 .

35. Two of the same three justices subsequently sat on the Nolin appeal.

36. (1977) 1 C.R. (3d) 186.

37. Supran. 13.

38. Supran. 12.

39. Supran. 13 at 181 .
} 
After disagreeing with the statement of Kelly J.A. in $R$. v. Keating ${ }^{40}$ regarding the Magistrate's “inherent jurisdiction to control his own proceedings", Ritchie J. continues: ${ }^{41}$

I am however, unable to subscribe to this opinion as I take the view that the careful and detailed procedural directions contravened in the Code are of necessity exhaustive, and as $I$ have indicated $I$ regard the powers of a Magistrate or Justice acting under the Criminal Code as entirely statutory.

The question is, are these statements intended to be confined to the facts and sections of the Code therein being decided upon or rather are they statements of the law applicable to the Criminal Code generally? As Chouinard J. confirmed in the decision in Sellars v. The Queen, the Supreme Court of Canada is not given to "idle chit-chat", and statements of the law made by their Lordships are binding upon Lower Courts. ${ }^{42}$

It is clear that in Davies, Clement J.A., for the majority of the Alberta Court of Appeal, decided that the ratio of Doyle is that the "powers of a magistrate or justice acting under the Criminal Code [are] entirely statutory" 43 and there is no statutory provision in the Code to permit such a re-election, prior to committal. He therefore concludes that Doyle effectively overruled Cooper and that being so, Cooper no longer overrules Scown. He distinguishes Broder as not being concerned with jurisdiction of the Magistrate, but only with whether or not the Crown's consent was necessary in order for the accused to apply to re-elect. This distinction, with respect, seems somewhat artificial, although Broder clearly states that that was the sole ground of appeal. In the end, Clement J.A. returns to Scown and holds that the jurisdiction of the Provincial Judge is confined to sections 465,475 and 484 of the Criminal Code. Thus the Magistrate has no jurisdiction to permit a re-election downwards to a Provincial Court trial during the course of a preliminary hearing. The Davies appeal decision upholds the ruling of the Provincial Court Judge. In Alberta, then, we may have come full circle to the situation where we were in Scown in 1945.

Shelley L. Miller, in her thorough article in the Alberta Law Review, ${ }^{44}$ dissects in considerable detail the majority judgment of Clement J.A. in Davies and purports to distinguish each authority relied upon by His Lordship. She concludes, respectfully, that the judgment was decided "per incuriam" and should not be considered as binding.

40. (1973) 11 C.C.C. (2d) 133 (Ont. C.A.),

41. Supran. 39.

42. (1980) 52 C.C.C. (2d) 345 at 347. Chouinard J. states: "However in Paradis v. The Queen (1977) 33 C.C.C. (2d) 387, a majority of the Court expressed the opinion that the same rule of caution must be applied to the testimony of an accessory after the fact as to that of an accomplice, and in my opinion, therefore, this is the interpretation that must prevail. As it does from time to time, the Court has thus ruled on the point although it was not absolutely necessary to do so in order to dispose of the appeal."

43. Supran. 12 at 13.

44. Supran. 11. 
Further, Miller concludes that the dissenting judgment of Prowse J. in Davies "is more in line with the weight of authority". ${ }^{45}$ Prowse J.A., in dissent, concluded that Doyle did not overrule Broder because the Supreme Court of Canada in R. v. Atkinson, which was decided after Doyle and dealt with facts "on all fours" with Broder, simply disposed of the Atkinson appeal without reference to Doyle by stating "since no plea was taken after the re-election permitted by the Magistrate"'. ${ }^{46}$ [Emphasis added] In short, Prowse J.A., in dissenting, held that Broder was still effective and binding upon him.

Since the Davies case began with the decision of Provincial Judge B.C. Stevenson, ${ }^{47}$ it would seem useful to look at that decision. In that case, the accused elected trial by judge and jury. The preliminary hearing proceeded for two full days, and then was adjourned for continuation, three weeks later. On that latter date defense counsel applied to convert downwards to a trial in Provincial Court, and the Crown would not consent thereto.

His Honour refused the application. In his clear and succinct judgment, His Honour first deals with the matter of "Discretion" and concludes that because of the use of the mandatory word "shall" in sections 491 and 492, he cannot accept the proposition in Broder that a Magistrate has a discretion to allow or refuse an application to re-elect. The word "shall" removes any discretion from the Magistrate and therefore His Honour stated: "I find that an application made by an accused under either section 491 or 492 will automatically result in a redefinition of the forum for his trial." ${ }_{48} \mathrm{He}$ then concludes that sections 491 and 492 preclude any application before the Magistrate until there has been a committal following the completion or waiver of the preliminary hearing. He distinguishes Broder in that it dealt only with "the narrow issue of the requirement of consent by the Agent of the Attorney-General", and furthermore, that it did not appear "to have had reference to the decision of the Supreme Court of Canada in R. v. Doyle". ${ }^{49}$ He then distinguishes Cooper, MacRitchie and Gray ${ }^{50}$ on their facts, and accepts the Crown submission that Doyle "rendered subsequent to the Cooper decision, represents the present state of the law in this area". ${ }^{51} \mathrm{He}$ concludes: "I find that at this stage of the proceedings before me I have no jurisdiction to deal with the application made under section 492 of the Code". ${ }^{52}$

45. Id.. Monnin J.A. in the Manitoba Court of Appeal in the 1979 decision of R.v. Matheson also supports Miller's view, in stating, "In expressing this view I find support in the judgment of Prowse J.A. in the Alberta case of $R e$ Davies and The Queen . . . as yet unreported."

46. Supran. 36 at 186 .

47. Vol. 2, Alta. Prov. Ct. Decisions 699.

48. Id.

49. Id. at 700 .

50. (1977) 38 C.C.C. (2d) 292.

51. Supra n. 49.

52. Id.. (In the judgement of Clement J.A., on appeal, section 492 was not spelled out in the Order of the Provincial Judge as quoted by his Lordship at page 3 , in the appeal.) (Procedurally, the accused moved for certiorari to quash the refusal or mandamus to order the provincial judge to hear the application to re-elect, which Kirby J. (Alta. Q.B.) refused. This refusal was upheld by the majority of the Alberta Court of Appeal.) 
It seems clear that the application to re-elect was based upon section 492 and, by inference, the submission was that section 492 should be interpreted so as to permit re-election before a committal. This position seems clearly against the weight of authority. Broder, MacRitchie, and the Provincial Judge concerned herein agree that s. 492 is applicable only after committal. Clearly the cases of Broder, Cooper, and MacRitchie were put forward in argument, in relation to the Magistrate's discretion. Clement J.A., in the appeal, deals with the submissions of defense counsel:53

Stevenson Prov. J. had jurisdiction, while in the course of the preliminary inquiry, to
entertain the application to re-elect and had a duty to exercise his discretion thereon. It
is urged that such jurisdiction exists either as inherent in the function of a Provincial
Judge, or by inference from provisions in the Code.

He clearly fixes the issue on the appeal as, "We are to determine whether an accused can re-elect his mode of trial during the course of a preliminary hearing." 54 - and certainly it is that issue that Their Lordships concern themselves with.

Clement J.A. also quotes from the original ruling in Davies by the Provincial Court Judge wherein the latter considered what the evidence would be if there was a re-election permitted:55

\footnotetext{
I might add that, despite the apparent agreement of counsel that evidence taken at a preliminary inquiry may form evidence in a trial had there been jurisdiction to convert that proceeding in the manner applied for, I have been unable to find any authority for that proposition, other than the 'strict proof' sections of the Criminal Code.
}

It will be observed that section $485(1)$ is not really considered anywhere in the original ruling or in the Court of Appeal judgment. It is respectfully suggested that whatever effect Doyle may have had upon Broder, it should not have diminished the significance of the statement of McDermid J.A. therein:"56 "Certainly in view of section $485(1)$ which allows the Magistrate to direct a preliminary hearing it would be necessary for the Magistrate to consent before an accused could insist the Magistrate try him ..." In particular, in Davies, Clement J.A. states, regarding Broder, ${ }^{57}$ "I emphasize that no issue was raised there, as it is in the present case, on the jurisdiction or power of the Provincial Judge to entertain an application to re-elect during the course of a preliminary hearing" and further" "Finally he referred to Millerv. The King . . . wherein the issue was whether it was necessary for the Magistrate to consent to a reelection, a point which he dealt with effectively and which is remote from the present considerations." To the same effect in Cooper, McKay J.A. states:59 "The Criminal Code makes provision for an accused charged with this type of offence to elect as to Court and mode of trial by a Magistrate (subject only to the right of the Magistrate under section $469(1)$ "' (now 485(1)).
53. Supran. 12 at 3.
54. Id. at 2.
55. Id. at 3 .
56. Supran. 8 at 59.
57. Supran. 12 at 11 .
58. Id. at 11-12.
59. Supran. 24 at 106-7. 
It is submitted that the Provincial Judge, in his original ruling, was persuaded that the discretion given to him under section $485(1)$ would be overruled by the mandatory word "shall" in sections 491 and 492 and had he jurisdiction he would have had no choice but to proceed as a trial. It follows then, that the only means to prevent what would have been a manifestly unfair position for the Provincial Judge (i.e. after listening for more than two days to a preliminary hearing spread over some three weeks, to find it converted to a trial which he must accept) was "want of jurisdiction," and Doyle could provide this.

It is to be noted that the same mandatory word "shall" is found in section 464 and section 484. Notwithstanding which, Fairbairn, Cooper, MacRitchie and Broder still found a discretion in the Magistrate to permit re-elections.

Even more to the point, $R e$ Neilson and The Queen, approved unanimously by the Supreme Court of Canada, held that "section 484 is overridden by and subject to section $485(1)$ ". 60 It is submitted that the mandatory wording in sections 491 and 492 is the same as, and is no more compelling, than the mandatory wording in sections 464 and 484, and that the ruling in Neilson should therefore apply, resulting in section 485(1) also overruling sections 491 and 492.

It will be recalled that in the Davies case in the original ruling, His Honour was also concerned about how evidence could be transferred from a preliminary hearing to a trial, simply by consent.

The matter was dealt with, subsequently, by the Supreme Court of Canada in Matheson v. The Queen, wherein Lamer J. stated:61

\begin{abstract}
As regards evidence by witnesses, strict compliance means their being sworn or affirmed and heard at the trial before the trier of fact. An accused may, if the Crown consents and the Court accepts, waive strict compliance with that rule in many ways and in various degrees; indeed, he may relieve the Crown from proving certain facts by admitting them; he may dispense with the swearing in of witnesses and the taking of their evidence by admitting what their evidence would be as regards certain facts if those witnesses were called; he may, if the evidence has already been adduced at a previous proceeding, accept that the evidence be read or even be deemed to be read into the trial proceedings; he may even accept, when as in this case the trial Judge is the same person before whom the witnesses testified in the previous proceedings, that their evidence be deemed read into the record of his trial without even awaiting the filing of the transcript of their oral evidence.
\end{abstract}

His Lordship goes on to state that there must be consent by the accused and the Crown to depart from strict compliance, which consent must be conveyed to the Court in the course of the trial, and by filing transcripts or by some reference to previous judicial proceedings, enter the record sometime during that trial. ${ }^{62}$

60. Supran. 4 at 533.

61. Supran. 2 at 291.

62. See also R. v. Hunter and McInroy, supra n. 17, where a new trial was ordered because no application was made to have the evidence heard at the preliminary become the evidence at trial. 


\section{POST DA VIES (DOYLE) CASE LAW AUTHORITY}

The majority decision in Davies regarding the application of Doyle finds support in the Newfoundland Supreme Court decision of Re Horwood and The Queen where it was held that the relevant statement by Ritchie J. in Doyle "was a pronouncement of general application" and that the accused had no statutory right to change his election upwards to a preliminary hearing at the outset of the date set for the trial. ${ }^{63}$ Similarly in the Manitoba Queen's Bench decision of R. v. Poitras, Morse J. states: "In view of the clear and precise words used by Ritchie J. I am not satisfied that it is proper for a trial judge to ignore them if, strictly speaking, they could be said to be obiter." ${ }_{64}$

Other decisions have gone the other way and have considered the relevant observations in Doyle not to be of general application. As mentioned earlier, Broder did not mention Davies. The Atkinson decision from Manitoba, at the Supreme Court of Canada level, made no mention of Doyle. In the Manitoba Court of Appeal decision, R. v. Matheson, it was stated by Monnin J.A. for the majority, "this conclusion is in no way affected by the decision of the Supreme Court of Canada in Doyle v. The Queen" and, as stated earlier, he agreed with the dissenting judgment of Prowse J.A. in Davies. ${ }^{65}$ Monnin J.A. also mentioned the result of the Atkinson decision in the Supreme Court of Canada. The Supreme Court of Canada decision of Lamer J. in $R$. v. Matheson clearly seems to confirm the right of the accused to re-elect during the preliminary downwards to a provincial trial, notwithstanding Doyle. Matheson went to the Supreme Court of Canada where Doyle was not mentioned; the grounds of appeal were not considered, and a new trial was ordered because the evidence at the preliminary hearing was held not to have been applied to the trial, and there was therefore no evidence at trial (as in $R$. v. Hunter and McInroy).

In R. v. Gray, Bull J.A. of the British Columbia Court of Appeal, speaking of the oft-quoted passage of Ritchie J. in Doyle, stated: ${ }^{66}$

In my respectful opinion that language was obiter dicta and that Ritchie J., thereby did not intend to deny inferior trial courts the power to cure or act on deficiencies in, or matters not covered by the Code . . I am unable to conclude that the decision of the Supreme Court of Canada in Doyle has had the effect of overruling Cooper, McRitchie, Broder...

He therefore held that the Magistrate had a discretion to allow the accused to convert a preliminary downward to a trial after the preliminary commenced. ${ }^{67}$

63. (1978) 42 C.C.C. (2d) 238 at $242-3$.

64. (1976) 6 W.W.R. 654 at 657 .

65. (1979) 50 C.C.C. (2d) 92 at 100 .

66. Supran. 50 at 295.

67. See also R. v. Bonnar (1980) 30 N.B.R. (2d) 700 which holds that once an accused has elected trial by judge and jury, then the jurisdiction of the Provincial Judge is confined to either holding a preliminary hearing, or taking a re-election for trial by Magistrate. In particular, he cannot permit a re-election to judge alone, even with Crown consent, and even before the preliminary hearing commences, because such re-election to judge alone arises only after a committal and is to be dealt with then by a Queen's Bench Judge (Superior Court Judge) at the arraignment, the committal having ended the jurisdiction of the Provincial Judge. 
The article of Mr. E. G. Ewaschuk entitled "The Wonderful World of Practice" 68 also suggests that the relevant remarks of Ritchie J. in Doyle should be considered obiter and should be restricted to the rather blatant factual situation in Doyle (i.e. that there was a loss of jurisdiction in those particular circumstances). In Doyle the Magistrate acted in direct conflict with the express provisions of the Code regarding adjournments, which no Judge could do, which is much more compelling than the situation regarding re-elections before committal, where the most that can be said is that the Code is silent.

Bell v. $R$ and Alder, ${ }^{69}$ a matter by Verchere J., in British Columbia Supreme Court Chambers, did not consider Doyle. Cooper and MacRitchie were followed and it was held that the accused had a right to elect upwards to a preliminary from a provincial trial. His Lordship even went so far as to prohibit any other Provincial Judge in British Columbia from hearing this matter as a trial.

In $\operatorname{Re}$ Diamonte and The Queen,70 Toy J. of the British Columbia Supreme Court dealt with the same "upwards" situation as in Bell v. $R$. and Alder and held that Doyle did not overrule MacRitchie. Where the petitioner was "mistaken and uninformed" regarding his election, a Provincial Judge should use his discretion to hear the accused's application to convert upwards. He suggested that Verchere J. in Bell v. R. and Alder had gone further than he had to in considering this a right, and following it with the prohibition order.

The Ontario Court of Appeal decision in Re Retzer and The Queen "1 did not consider Doyle but they would have been aware of it, as Toy J. in Diamonte stated in concluding that although the accused had no right to re-elect upwards to a judge and jury, there being no such statutory right, nevertheless, the Magistrate does have the jurisdiction to "entertain" the application of the accused to withdraw his election and re-elect as if he had made no prior election. This appears to be the culmination of the position begun in Siniaski and enlarged slightly in Miller.

As was pointed out by Doherty in Study 7, entitled "Elections and ReElections", the result in Ontario now is that "while an accused may not re-elect unless he comes within the relevant Code provisions, he may make application to withdraw his election and elect anew", which "matter is entirely within the discretion of the Magistrate", and not dependent upon Crown consent. ${ }^{72}$

The recent decision in $R$. v. Krem ${ }^{73}$ of Clare Lewis P.C.J. of the Ontario Provincial Court is interesting. His Honour reviews the law on reelections and follows Retzer and Cooper in holding that the right to apply to re-elect was to be found by "necessary impliction", in accordance with the words used by Ritchie J. in Doyle. He suggests that sections 491 and

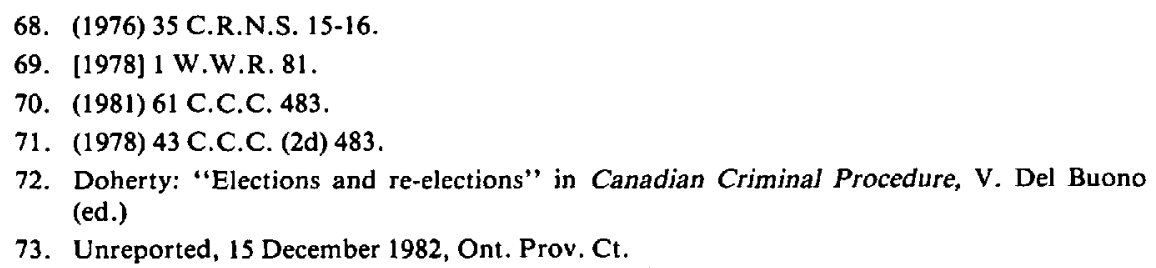


492 did not deal with re-elections before committals for trial because the legislators accepted that the law relating thereto was decided by Cooper and Fairbairn. Why, he asks, would one have to complete a preliminary hearing and then re-elect downwards with Crown consent (as per sections 491 and 492) if all the parties consent thereto beforehand? He therefore concludes that such power to do so must be there as a "necessary implication". The reason why Crown consent is necessary after committal is because the jurisdiction of the Provincial Court is ended with a committal, and it can only be re-vested with express statutory authority (i.e. in sections 491 and 492) which, by the terms thereof, requires the consent of the Crown.

His Honour agrees that there is no right to re-elect, only the right to apply to re-elect, and "fairness" should determine the success or failure of the application. The particular case he deals with involves an attempted rape charge. Crown Counsel, with the help of leading questions, apparently had a Crown witness change her answers regarding identification. His Honour concludes that in those circumstances only the same Court could best give proper consideration to that issue. In doing so he also recognizes the wide discretion enjoyed by the accused to choose his forum for trial, acknowledging as well that the Crown could still utilize its overriding power in section 498 to still insist upon a trial by judge and jury and thus have a preliminary hearing notwithstanding, since the particular charge concerned was punishable for more than five years.

This latter acknowledgement suggests the clear possibility that the whole procedure of a re-election downwards, both before and after committal, at least as regards serious charges, could thereby become an exercise in futility. It seems clear from the wording contained in section 498 , and from the interpretation thereof by McKay J. in the British Columbia Supreme Court Chambers in Re Essiambre and The Queen that sections 498 and 507 (direct indictment) "necessarily contemplate an interference with the usual rights of election and re-election" and apply "notwithstanding the absence of an election by the accused", and further the "sections are not limited in their application to a superior Court of criminal jurisdiction"' ${ }^{74}$, Even though the Crown has consented to a reelection pursuant to section 491 or 492 , that consent can be effectively cancelled by the Crown invoking section 498 , resulting in a preliminary hearing (unless one has already been held) and a trial before judge and jury. ${ }^{75}$ In practice, the opportunities for the Crown to invoke this "ultimate procedure" would probably be infrequent, in any event. It is suggested that where a re-election downwards has been granted, the right of the Crown to recall any or all of its witnesses who gave evidence at the preliminary hearing to that point, or if they are not available, to request an adjournment, should be sufficient to allow the Crown a fair opportunity to present its case.

74. (1974) 17 C.C.C. (2d) 44 (B.C.S.C.).

75. See also Regina v. Pontbriand (1978) 39 C.C.C. (2d) 145 (Que. Sup. Ct.), where it was held that the previous consent of the Attorney General to a re-election from trial by judge and jury, to judge alone, did not preclude the Crown from invoking section 498 and thereby having a trial by judge and jury, notwithstanding. The rather compelling factual situation therein might have had some significance. 
Indeed, it may well be that this avenue of jurisdiction by necessary implication regarding re-election downwards is virtually the only response possible to Doyle since the Supreme Court of Canada in $R$. v. Chabot seems clearly to be returning to Doyle. Dickson J. in Chabot states: ${ }^{76}$

It is critical, as it seems to me, to commence the inquiry with an analysis of the provisions of the Code.

If the power to commit for trial in offences other than those specified in the information exists, such power must be found in the Code either expressly or by necessary implication. This is evident from the opinion of Ritchie J. in Doylev. R. supra at p. 602 where he stated:

Whatever inherent powers may be possessed by a superior court judge in controlling the process of his own Court, it is my opinion that the powers and function of a Magistrate acting under the Criminal Code are circumscribed by the provisions of that statute and must be found to have been thereby conferred either expressly or by necessary implication.

It is conceded by the Crown that nowhere is a power to commit for a greater of fence expressly conferred by the Code. It is manifest that Parliament conferred such power by necessary implication. [Emphasis added.]

Apropos of this reasoning is the recent decision of the Court of Appeal of Alberta in Norman Scott v. The Queen. There it was held that "There is no express provision in the Criminal Code granting this power, it arises by necessary implication." "77 As a result, the Court upheld the decision of the Judge who heard the preliminary hearing, and granted the Crown request at the end of the evidence, but before committal, to amend the Information and add the necessary word "corruptly" pursuant to section 473(c) of the Code. Section 473(c) provides that:

The validity of any proceeding at or subsequent to a preliminary hearing is not af fected by:

(c) any variance between the charge set out in the summons, warrant or information and the evidence adduced by the prosecution at the inquiry.

In the Scott decision the Court refers to the judgment of $R$. v. Chabot wherein Dickson J. states "The 'variance' of which 473(c) speaks, must, I think be regarded as a variance in respect of such matters as name, places, dates and the like." 78 Scott holds that the "variance" aforesaid would also cover a word omitted in the Information but adduced in the evidence. The Court then concludes that "such being the case, I think it implied, the provincial judge has the power to amend the Information to conform to the evidence, where the accused has notice of the section under which he is charged and which contains the 'omitted word'." 79

76. (1980) 18 C.R. (3d) 258 at 274.

77. R.v. Scott (1983) 42 A.R. 135 (Alta. C.A.) at 138.

78. Supran. 75 at 278.

79. Supra n. 77. One would infer from this that the section number of the Code was shown on the face of the Information. 
Of interest also is the thorough article by John A. Olah entitled "The Doctrine of Abuse of Process: Alive and Well in Canada". ${ }^{80}$ This article predates Chabot and this may affect Olah's statement regarding Doyle : 81

It is submitted that Doyle is merely authority for the proposition that where the procedural directions laid down by the Code are exhaustive, as for example, in the case of adjournments under Part XIV, the Code excludes any attempt by a Magistrate to act in contradiction to such procedural directions pursuant to his inherent powers. In other words the specific statutory provisions exclude the exercise of such inherent power and any deviation from these exhaustive provisions results in a loss of jurisdiction. The case does not stand for the proposition that there is no inherent jurisdiction in a Provincial Judge.

\title{
D. CAN DAVIES BE RESTRICTED IN ITS APPLICATION IN ALBERTA?
}

It will be remembered that Alberta Provincial Court Judge J.P. Wambolt in his paper "The Preliminary Inquiry - Re-election of Magistrate Without Jury" 82 suggested that perhaps Davies could be confined to reelection under 492 (judge and jury) and considered as not applying to 491 (judge alone). This appears to be contrary to Broder which concludes that for re-election purposes 491 and 492 shoud be considered the same and to the same effect. ${ }^{83}$ However, there may well be support for Judge Wambolt's contention in the statement of Lamer J. of the Supreme Court of Canada in Matheson: ${ }^{84}$

\begin{abstract}
As the accused had elected to be tried by a judge without a jury and the Crown had chosen to proceed on the first count the Magistrate commenced a preliminary inquiry into that of fence. After twelve witnesses were examined, the appellant moved to re-elect for a trial by a Magistrate under Part XVI, as is permitted in accordance with the provisions of s. 491 of the Code. [Emphasis added.]
\end{abstract}

This seems to recognize the right of the Magistrate to accept an application to re-elect part way through a preliminary hearing. Is His Lordship also interpreting s. 491 so that it applies to a re-election prior to committal ? $^{85}$ If so, this seems to support the submission of Judge Wambolt that Davies could be restricted to s. 492 re-elections downwards from judge and jury and thereby not have application to s. 491 re-elections downwards from judge alone.

The statement above of Lamer J. in Matheson certainly would seem, at the very least, to restrict Davies to a s. 492 (from judge and jury) reelection only. One could surmise that in fact, Matheson completely overrules Davies. It is to be noted that Martin's Annual Criminal Code

80. John A. Olah, "The Doctrine of Abuse of Process: Alive and Well in Canada" (1978) 1 C.R. (3d) 341 .

81. Id. at 363-364 In a somewhat parallel vein, perhaps suggesting interpretations away from strict compliance with Doyle, see R. v. Geszthelyi (1977) 33 C.C.C. (2nd) 543 (B.C.C.A.) where it was held that failure to put the accused to his election on his first appearance did not result in the Provincial Court losing jurisdiction over the accused because section 484 only sets out the procedure to be followed and not the time to make the election. However. once again this decision was before Chabot.

82. Supra n. 7.

83. See R. v. Gray, supra n. 45 where it was conceded that no valid distinction could be made between ss. 491 and 492 for the purpose of appeal.

84. Supran. 2 at 290. 
(1982), dealing with decisions under section 491 of the Code, cites the cases of MacRitchie, Cross and Matheson as authority for the statement that: ${ }^{86}$
A Provincial Court Judge has a discretion to permit an accused who has elected trial by a Judge alone to re-elect trial before him prior to his committal for trial notwithstanding that the consent of the Attorney-General has not been obtained.

Matheson is an unanimous decision of the Supreme Court of Canada (the coram included Ritchie J.) delivered in June, 1981 which was one year after Chabot and two years after Davies. It may well be argued therefore that Davies has been effectively overruled by Matheson, yet Matheson did direct a new trial because the evidence from the preliminary hearing was not applied to the trial. With deference to Martin's, that point may well be the ratio of the case, and the part of the judgment dealing with re-elections may be obiter only. It may, of course, also be a statement of the law.

It is of interest that in Diamonte, Toy J. states: ${ }^{87}$

If I had to consider the case without the benefit of the line of authorities that include Cross, MacRitchie, and Bellv. R. and Alder, and if I only had the guidance of Doylev. The Queen, I would say that surely it follows logically that "a magistrate" sitting as Part XVI Judge at a serious trial has the discretion applied for here by the petitioner as a "power . . . conferred . . . by necessary implication", as envisioned by Mr. Justice Ritchie. For an accused person to receive a fair trial, whether he be truly a Magistrate without a jury, a Judge with or without a jury or a Supreme Court Judge sitting with a jury, the judges sitting in those four forums must have equivalent powers.

It may also be relevant at this point to also recall Ritchie J.'s statement in Doyle as follows: ${ }^{88}$

In my view, the whole structure of the procedural provisions of the Code which deal with the treatment of process immediately after they have been arrested is designed to provide a speedy disposition of their cases.

Certainly many re-election applications would be for this purpose.

In Retzer, $^{89}$ it will be recalled, the accused was permitted to withdraw his election and make a re-election by a new election without requiring the consent of the Crown. This would appear to be the ultimate point in the progression from Siniaski and Miller. Retzer involved a re-election upwards from a Provincial Court trial but, on principle, it would not appear to be restricted thereto. Some support for this position in Alberta may be found, by analogy, by referring to $R$. v. Bercov ${ }^{90}$ which although involving matters exclusively within the jurisdiction of the Supreme Court of Alberta, held that an accused could withdraw his consent to trial by a judge alone and could have a trial by judge and jury, up to any time prior to the commencement of the trial.

It is suggested that the judicious use of section $485(1)$ by the Provincial Judge could also be helpful. First, as regards re-elections upwards, if defence counsel makes out a case then this wide discretion could be exercised at any time. Indeed in two recent cases in Alberta, the Provincial

85. Such an interpretation could be contrary to MacRitchie and Broder.

86. Greenspan's Martin's Annual Criminal Code (1982).

87. Supran. 69 at 488.

88. Supran. 11 at 185.

89. Supra n. 70.

90. (1949) 96 C.C.C. 168. 
Judges on their own initiative did convert the trial to a preliminary. In one case before Provincial Court Judge Friedman in Edmonton, he did so because defense counsel mistakenly thought the proceeding was a preliminary hearing, where in fact, it was a trial. In an unreported case at Lethbridge, $R$. v. Sackman, October 28, 1980, before Provincial Judge R. Jacobson, he did so, because a rather "unhappy" situation was alleged, which reflected upon counsel's degree of preparation and readiness for a trial. It is clear that the Provincial Judge's discretion under 485(1) is not dependent upon the consent of the accused nor upon the Crown's consent. ${ }^{91}$

The Broder decision is also clear authority for the proposition that the Magistrate's consent to a re-election by the accused either downwards or upwards, is necessary. The same section $485(1)$ is the authority by which McDermid J.A. in Broder, later observing that Miller was a case where the Magistrate would not consent to the re-election, states: ${ }^{92}$

Certainly in view of section $485(1)$ which allows the Magistrate to direct a preliminary hearing, it would be necessary for the Magistrate to consent before an accused could insist the Magistrate try him ...

\section{A POSSIBLE EXPLANATION OF SCOWNAND DAVIES}

It will be recalled that Davies purports to restore Scown to the Alberta scene. In the Scown case the Magistrate "reluctantly" converted the preliminary downwards into a trial, but in Davies the Provincial Judge found that he had no jurisdiction to do so. In Scown Harvey C.J.A. states: ${ }^{93}$

The Magistrate seemed to think that he must accede to the request to convert the preliminary into a trial but thought it unfair to him. I assume that he thought that he should grant the request only because of the practice which he had been following because he is of course familiar with the terms of section 784 and knows he is not legally bound to do so.

Section 784 is similar to our $485(1)$ except that it specifically includes a previous conviction as a circumstance to consider and contains the phrase "or from any other circumstance", and uses the words "before the accused has made his defence" rather than "at any time before the accused enters upon his defence" as in s. 485(1). In Davies no mention was made of section 485(1) in the Provincial Court ruling nor in the Appeal Court decision, except in passing.

What may have happened in both cases, it is respectfully suggested, is as follows: Harvey C.J.A. applied a strict legalistic approach as a "sword" to the situation in Scown, where it appears abundantly clear that the Magistrate should have exercised his discretion in 784 (he was deemed to have been aware of 784) and should have refused to permit the re-election downwards to a trial. This was especially so, since the preliminary had been spread over two or three adjourned sittings, and the Magistrate felt it was unfair to himself, because he had been listening as at a preliminary and not as at a trial (in particular not weighing the

91. The same concerns expressed earlier herein regarding the evidence might have application here, if the Crown's refusal to consent to having the evidence at trial apply to the evidence in the preliminary where the discretion was exercised after the trial commenced.

92. Supran. 8 at 59.

93. Supran. 15 at 282. 
evidence). His Lordship concluded, very clearly, that defense counsel had been "converting a judicial proceeding into a game"'.94 There was a conviction and in these circumstances perhaps it may not be fair, or appear to be fair. Clearly, the reaction of the Magistrate to the evidence at the preliminary was being considered by defense counsel as a factor in his ultimate decision to re-elect to a trial, which in a sense, is placing the Magistrate "into the arena". ${ }^{95}$

In short, it is suggested that rather than simply criticize the Magistrate for failing to exercise "his wide discretion" under section 748 (485(1)), and ultimately leave a rather bad situation unaltered with the likelihood that such cases might continue in the future, in accordance with the Magistrate's "common practice" in the "Police Court", it may have been more judicious to correct this case, and end this practice by determining that the Magistrate, in such circumstances, had no jurisdiction.

In a somewhat similar vein, Clement J.A. in Davies, by applying Doyle as he did, reverted to the Scown position and thus was able to apply the "no jurisdiction" position as a "shield" to uphold the Provincial Judge's decision in refusing to let the accused re-elect. It is respectfully submitted that the Provincial Judge could have decided, simply, that he would not consent in any event by virtue of section 485(1). Broder and other cases have held that that is the effect of that section and that could have ended the matter. In any event, the accused would have had a very difficult time trying to establish that the Provincial Judge wrongfully or unfairly exercised his discretion under 485(1) in all the circumstances of that long, protracted, preliminary hearing. Indeed one might, with great respect, venture to suggest that the entire Davies proceeding could have been considered as a case where the Magistrate, impliedly, did exercise his discretion under $485(1)$, and refused his necessary consent to any reelection. As Harvey C.J.A. stated in Scown, "he is of course, familiar with the terms of section 784 (virtually now $485(1)$ ) and knows that he is not legally bound to do so.' 96

In brief summary, it may be suggested that section $485(1)$ is in the Criminal Code only to enable a Magistrate, who "for any reason" believes that he should not be hearing a trial, to convert the proceeding into a preliminary hearing; nevertheless, the decisions of $R$. v. Broder, $R$. v. Fairbairn, and others have enlarged the interpretation of this section

94. Id.

95. This may, of course, always be a factor, but certainly counsel should not make this as obvious as he did in the Scown case. In Scown at the time of the election, defence counsel stated to the Magistrate: "I am appearing Sir, I am going to elect for a preliminary hearing but I probably will ask Your Worship to change the election later on, if Your Worship will hear me." In commenting on this, Harvey C. J.A. in Scown states at p. 252:

I think there can be no doubt that if Mr. C.___ instead of using the words he did, expressed what was his real reason, he would have said: "I would like to wait before deciding whether to have you try the case till $I$ hear the evidence and get what inkling I can of the impression it makes on you, when I will be in a better position to advise the accused." If $\mathrm{Mr}$. C. did not mean that, certainly the practice leaves the opening for such a situation and for converting a judicial proceeding into a game.

That's pretty strong stuff!

96. Supran. 93. 
so as to conclude that the Magistrate's consent is necessary to effect any re-election downwards to trial before him. Furthermore, if the Magistrate does not so consent, then he cannot be compelled to hear the matter as a trial, notwithstanding the election of the accused in the first instance for trial before him. ${ }^{97}$ It is submitted that the position of the accused would be no better on his re-election (the same mandatory word "shall" is used in both applicable sections) and therefore the Magistrate's refusal to consent would also override the "right" or "right to apply" of the accused for any re-election under sections 491 or 492.

\section{POTENTIAL USE OF SECTION 485(1) AND OTHER COURSES OF ACTION IN VARIOUS SITUATIONS}

It has been suggested herein that section $485(1)$ is rather an extraordinary section, and it is submitted that greater use could be made of section $485(1)$ by itself or in conjunction with other courses of action. The following circumstances could call for such consideration:

A. As to proposition (b) spelled out at the outset of this paper-re-election upwards from a Provincial Court trial to a preliminary hearing-although clearly there is no statutory right to do so, it would seem that whenever a "fair" case was made out to do so, that section 485 (1) could be used to bring this about, with or without Crown consent, at any time "before the accused has entered upon his defense". Indeed, this has already been done in Provincial Court in Alberta.

B. As to proposition (a) spelled out at the outset of this paper-re-election downwards from a preliminary hearing to a trial in Provincial Court-the case is not as clear, particularly so as a result of $R$. v. Davies, but the following proposals are submitted:

1. If the preliminary hearing has not yet commenced, it would seem that the Provincial Judge can accept a reelection downwards for a guilty or not guilty plea if the Crown consents and he, himself, agrees.

2. In circumstances the same as in 1 . above but where the Crown does not consent, the Provincial Judge could likely still entertain the application to re-elect but he may want to consider an adjournment if it is "unfair" to the Crown, or he may hear the application and refuse to consent.

3 . If the preliminary hearing has commenced and the reelection application is made in circumstances which would be "unfair" to the Magistrate (such as in Scown or Davies ) or "unfair" to the Crown (such as in Atkinson), then the Magistrate can certainly use his discretion under $485(1)$ and refuse to consent. This would end the reelection without the necessity of dealing with the matter of determination of his jurisdiction.

97. Supran. 4. 
4. In circumstances the same as in 3., where both the magistrate and the Crown consent and there is going to be a guilty plea, then notwithstanding Scown, Davies, and the observation of Laskin J.A., in dissent, in Fairbairn regarding the irrelevance of a guilty plea in determining jurisdiction, it is suggested that most Provincial Courts would entertain the re-election application and take a guilty plea, being perhaps of the view that, in those circumstances, and with counsel, that it would be a "travesty" to later permit the accused to attack the Magistrate's jurisdiction (having requested it and having submitted to it). ${ }^{98}$

5. In circumstances the same as 3 ,, but where there is going to be a not guilty plea and a trial, and both the Crown and the Magistrate consent, then it is suggested that to proceed with a simple re-election might be risky, and that an unhappy accused or an unhappy Crown, following conviction or dismissal, might invoke Davies and challenge the jurisdiction of the Provincial Court. The safer procedure might be to discharge the accused and have a new Information drawn and a new election given thereon, in which case the presiding Provincial Judge could probably continue to sit on the case. Alternatively, the presiding Provincial Judge might consider declaring a "mistrial" leading to a new Information and a new election with the proceeding following in front of a different Provincial Court Judge. Also, the preliminary hearing could be completed or waived, resulting in a committal and then a reelection back to Provincial Court, with Crown consent, under section 491 or 492 , which seems rather cumbersome. Consideration could also be given to the procedure suggested in $R$. v. Retzer where the accused was permitted to withdraw his election and re-elect (the ultimate point in the progression from Siniaski and Miller and The Queen ), with or without the consent of the Crown. ${ }^{99}$

6. In circumstances the same as 5 . but where the Crown does not consent, Davies may well apply and it would certainly seem to be fair to assume that the re-election may not be granted, for want of jurisdiction. Again, the Magistrate could refuse to consent in any event under 485(1).

In addition to the foregoing, sections 491 and 492 are, of course, available for re-election downwards after committal, with the consent of the Crown. It is submitted that $R$. v. MacRitchie and $R$. v. Broder have

98. See Fairbairn, Hunter and McInroy and Miller. The unreported Alberta Court of Appeal case of R. v. Bishop in August, 1978 (appeal \#11530) deals with this also. There, with Crown consent, a preliminary inquiry was converted downwards to a trial in Provincial Court at the end of the Crown case. After conviction the accused appealed on the grounds of "no jurisdiction" in the Provincial Court to allow the re-election. The Court of Appeal held that the accused was bound to his unequivocal agreement, and could not succeed.

99. But see infra, regarding whether Bercov could be used to bring this to Alberta. 
interpreted sections 491 and 492 as applying only to re-elections after committal, because they accepted the proposition that $R$. v. Cooper had confirmed that the right to re-elect downwards before committal was firmly established prior to the enactment of 491 and 492, and that those two sections were enacted, simply to fill in the void pointed out in Cooper and provide the means to re-elect after a committal.

In a parallel vein $K r e m$ suggests that 491 and 492 do not mention reelections before committal because Cooper and Fairbairn had resolved that matter. It is clear that prior to $R$. v. Doyle an accused had the right to apply to re-elect downwards for a trial in Provincial Court without Crown consent anytime prior to committal, and with Crown consent after committal. This would seem to be a most fair position and the overriding power of the Magistrate in 485 (1) to withhold his consent could ensure that such re-elections only took place when there would be no "unfairness" to any of the parties concerned.

How ironic it is that a case dealing with matters completely remote to re-elections should come before the Supreme Court of Canada in $R$. v. Doyle, and that two short statements made therein which, with respect, do not seem to be that necessary to the judgment, have been lifted out of that judgment and have become the means in $R$. v. Davies to virtually bring to a halt a nearly ideal system of dealing with re-elections in the Provincial Court of Alberta. The effect of the Davies case appears to be that Scown has been revived in Alberta and regarding re-elections in Provincial Court, we have gone back to 1945. Without intending any disrespect, it seems fair to make the observation that the Provincial Courts of the 1980's are not the same as the "Police Courts" of the 1940's, and the Provincial Court Judges of the 1980's are not the same as the "Police Magistrates" of the 1940's.

It must be stated quite candidly that although this paper suggests that section $485(1)$ is a rather extraordinary section and should be utilized more often, that suggestion is made within the context of the implication in $R$. v. Broder that it is a means of ensuring that applications for reelections both downwards and upwards in Provincial Court could be granted where it was fair to all the parties concerned. Where it was unfair to do so the Magistrate could exercise his overriding discretion in section $485(1)$ and refuse to consent. If, as a result of $R$. v. Davies, a Provincial Court Judge is considered to have no jurisdiction to entertain an application to re-elect once a preliminary hearing has commenced, then most of the ammunition will be taken away, leaving only applications downwards before the preliminary starts and applications upwards, which are really negative applications divesting jurisdiction from the Provincial Court from a trial to a preliminary hearing.

Further, one might wonder about the logic of permitting a re-election downwards after a committal but not before, when the very reasons that make the re-election desirable, namely expediency, expense, urgency to get it over with, availability and interest of witnesses, would seem to cry out for the trial to be at the earliest possible moment. It seems fair, as well, to observe that with no concern about a possible application for reelection downwards until after a committal (and then only thereafter, with the consent of the Crown) and being well aware of the rather low 
standard of committal for trial at a preliminary hearing, the Crown would be able to take rather weak and even questionable cases to a preliminary hearing and still be assured of getting a committal on the vast majority of them. Indeed, it is possible to conclude that with the number of criminal trials being dealt with in Queen's Bench resulting in a "Stay of Proceedings" or a dismissal following "no evidence called" that this may already be happening.

Finally, it has been suggested by Alberta Provincial Court Judge Darlene Wong that a refusal to permit a re-election during a preliminary hearing might be, arguably, an infringement of the right of an accused to be tried within a reasonable time under section 11(b) of the Canadian Charter of Rights and Freedoms.

\section{WHAT OF THE FUTURE?}

There is presently before the House of Commons, Bill C-21, which had first reading in November 1978 but has not yet been passed. Bill C-21 proposes changes to the Criminal Code regarding re-elections by repealing sections 491 and 492 and replacing them with a new 491 as follows:

Section 491(1) An Accused who elects or is deemed to have elected a mode of trial under Part XV or this Part may, at any time before the completion of his preliminary inquiry,

(a) re-elect as of right any mode of trial other than a trial by magistrate without a jury; or

(b) re-elect trial by magistrate without a jury with the consent of the prosecutor,

and thereafter may re-elect any mode of trial only with the written consent of the prosecutor.

(2) A re-election under this section other than one made during a preliminary inquiry, shall be made by the accused giving notice to a magistrate, clerk, or sheriff of the court of his original election that he wishes to re-elect, together with the written consent of the prosecutor, etc. [Emphasis added.]

Through this proposed new section, re-elections upwards or downwards to a judge, or judge and jury, will become a right. Reelections downwards to a Provincial Court trial, however, will require the "prosecutor's consent" if before committal, 100 and by the proposed Criminal Law Amendment Act, 1983, section 491(2) as am. would permit the accused to re-elect upwards from a provincial trial to a preliminary hearing, as of right, up to 14 days before the trial date, and thereafter with the written consent of the prosecutor. At least the section does purport to deal with re-elections during a preliminary hearing, although it would be less available than under Broder and MacRitchie because this new "statutory right" would require the Crown's consent whereas the aforesaid cases did not. The new section would go along the road some distance in re-opening the door to re-elect during the preliminary hearing, which door may have been shut in Alberta as a consequence of Davies. Section 485(1) is not included in Bill C-21, nor in the proposed Criminal Law Amendment Act, 1983; this new statutory right to re-elect downwards would likely still be subject to the Magistrate's approval under section $485(1){ }^{101}$

100. In practice would this be limited to when there is going to be a guilty plea?

101. However, the supremacy of $485(1)$ in these circumstances may well be challenged once again, notwithstanding Neilson. 
Finally, the Law Reform Commission in 1978 proposed that there be an absolute right to re-elect up to seven days after committal, and thereafter only if the accused can show "valid cause and, in addition, if the Crown and the Court of original election both agree". ${ }^{102}$

\section{CONCLUSION}

It is submitted that some means should be found to ensure that reelections upwards and downwards in Provincial Court can be made as easily as possible, where the same will best serve the ends of justice. Certainly a delicate balance must be struck to ensure that any such reelection will be fair to the accused, to the Crown, and to the Court, or, putting it more accurately, so as not to be unfair to any of these parties.

At the present time, the right to apply to re-elect after a preliminary hearing has commenced and before committal, in Alberta, has been virtually removed by $R$. v. Davies. Davies has revived the situation as it was in 1945, in Scown and as was suggested herein, the Scown decision could have been prompted by its particular situation. It is the position of this paper, respectfully submitted, that the present situation in Alberta is unfortunate and that the practice followed in $R$. v. Broder better serves the ends of justice.

102. "Elections and Re-Elections," Report on Criminal Procedure, Part I, Miscellaneous Amendments, Feb. 23, 1978 at 6. 